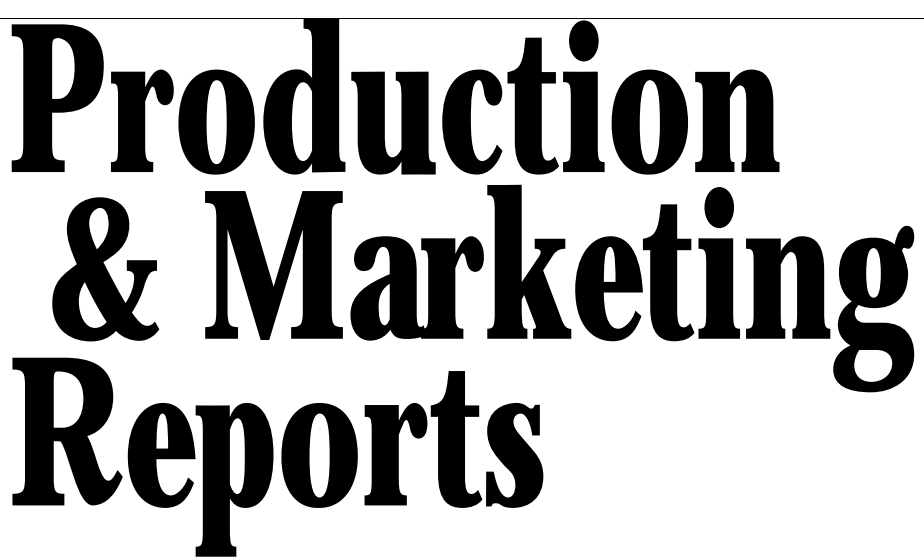

\section{Costs and Returns of Growing Selected Medicinal Herbs in New Mexico Indicate Positive Return to Land and Risk Likely}

\author{
Constance L. Falk, ${ }^{1} \mathrm{H}$ ildegard \\ van Voorthuizen, ${ }^{1} \mathrm{M}$ arisa $\mathrm{M}$. \\ Wall, ${ }^{2}$ Steven J. Guldan, ${ }^{3}$ \\ Charles A. M artin, ${ }^{3}$ and \\ Kathryn M. Kleitz ${ }^{2}$
}

AdDitional INDEX WORDS. cost and return estimates, Echinacea purpurea, Valeriana officinalis, A nemopsis californica, yerba mansa

This work was supported by the $\mathrm{N}$ ew $\mathrm{M}$ exico Agricultural Experiment Station, N ew M exico State U niversity, Las Cruces, NM, and the USDA Agricultural $M$ arketing Service, Federal-State $M$ arketing I mprovement Grant program. U se of trade names does not imply endorsement of the products named nor criticism of similar ones not named. The cost of publishing this paper was defrayed in part by payment of page charges. U nder postal regulations, this paper therefore must behereby marked adverti sement solely to indicate this fact.

${ }^{1}$ D epartment of Agricultural Economics and Agricultural Business, N ew M exico StateU niversity, L asC ruces, NM 88003.

${ }^{2}$ Department of Agronomy and $\mathrm{H}$ orticulture, $\mathrm{N}$ ew M exico State U niversity, Las Cruces, N M 88003.

${ }^{3}$ Alcal de Sustainable A griculture Science Center, N ew M exico State U niversity, PO Box 159, Alcalde, N M 87511.

Hortlechnology • O ctober-D ecember 1999 9(4) both sites, but was not included in this report because the commercial market is small, and the plant is easily harvested in the wild over much of the U.S. Little economic analysis has been published regarding medicinal herbs, although the potential for commercializing echinacea asacut flower hasbeen studied (Starman et al., 1995).

E chinacea is widely used as an immunestimulant and hasachieved popularity for its antiviral properties (Foster, 1991). Valerian is used to treat nervous tension, particularly anxiety and insomnia (H obbs, 1993). Although not well known outside of thesouthwestern U.S., yerba mansa is used for healing small infections, intestinal and urinary tracts, and sore throats, and has been suggested as an alternative to goldenseal ( $H$ ydrastis canadensis L.) (M oore, 1989).

Echinacea (which includes $E$. purpurea, E. angustifolia DC, and E. pallida (Nutt.)) was the top selling medicinal herb in 1997 through all marketing channels, accounting for $9 \%$ of the $\$ 3.6$ billion in consumer herb sales (Brevoort, 1998). Valerian was ranked 10th in 1998 and 18th in 1997 in natural food market sales. $M$ ass market sales of valerian for the 52-week period ending in mid-July 1998 werean estimated \$8 million (Brevoort, 1998). The size of the yerba mansa market is unknown as it has only recently begun to appear in herb industry publications. Yerba mansa has been recommended for increased commercial production because its native range is limited or threatened (Knight, 1999).

\section{Materials and methods}

T wo growing sites in N ew M exico were chosen for the experiments. In northern $\mathrm{N}$ ew $\mathrm{M}$ exico, the herbs were grown at the Alcalde Sustainable Agriculture Science Center in Alcalde on a Fruitland sandy loam, [coarse-loam, mixed (calcareous), mesic Typic Torriorthent] at an elevation of $5,690 \mathrm{ft}$ $(1,730 \mathrm{~m})$. Alcalde had an annual average 152 frost-free days from 1994-98 ( $N$ ew M exico State U niversity, 1998). In southern $\mathrm{New}$ M exico, the plots were located at the Fabian G arcia Agricultural Science Center in Las Cruces. The soilsthere are G lendale loam [ finesilty, mixed (calcareous), thermic Typic Torrifluvent] and the elevation is 3,900 $\mathrm{ft}(1,186 \mathrm{~m})$. The average frost-free growing season is $220 \mathrm{~d}$ (H errera, 1989).

The experiments started in early spring 1995 and continued through fall 1996. All species were established 
T able 1. Key cost assumptions for wages, taxes, utilities, interest, employee benefits, and management/supervision. ${ }^{2}$

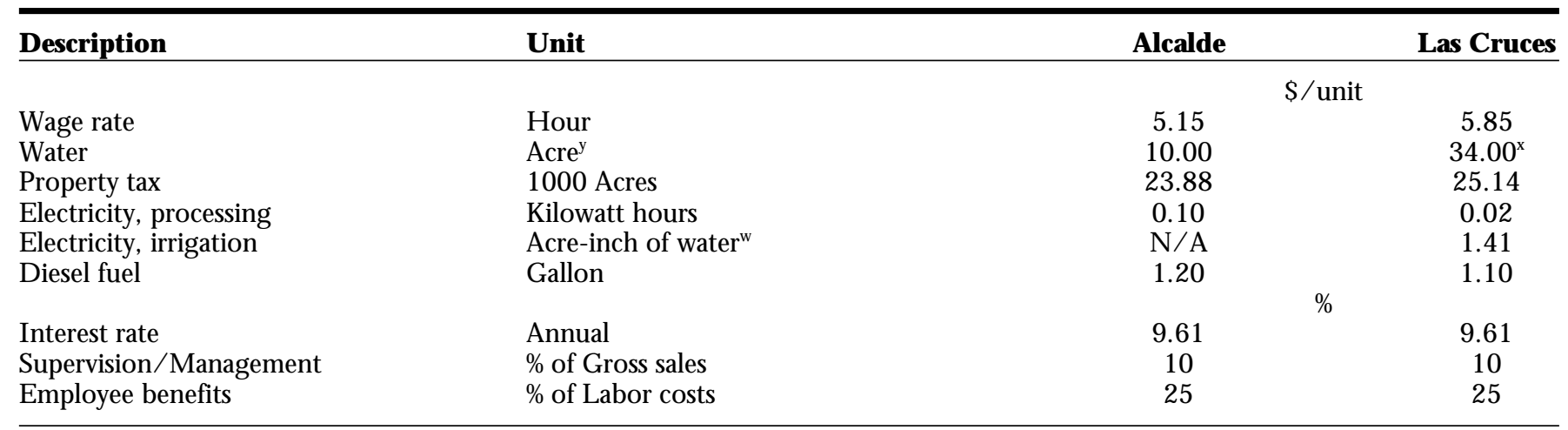

\footnotetext{
2Sources: Libbin and $\mathrm{H}$ awkes, 1996; Libbin and $\mathrm{H}$ awkes, 1997.

y1 acre $=0.4047$ ha.

XAdditional water over 2 acre-ft costs $\$ 14 /$ acre- $\mathrm{ft} ; 1$ acre- $\mathrm{ft}=43,560 \mathrm{ft}^{3}=1,233 \mathrm{~m}^{3}$.

w 1 acre-inch $=3,630 \mathrm{ft}^{3}=103 \mathrm{~m}^{3}$
}

through transplantsstarted from seed in agreenhouse, except yerbamansa, which was established using crowns harvested from the wild. Although these crops were not planted on land certified as organic, no synthetic fertilizers or pesticides were used. In the first year of the experiment, val erian wasplanted at both sites. $\mathrm{H}$ owever, valerian did not survive in Las Cruces. Therefore, yerba mansa was substituted for valerian in the second year of the trial in Las Cruces. The crops harvested in this experiment for the purpose of recording yield datawere 18-month echinacea and valerian roots, and 1-year yerba mansa roots.

In Las Cruces, all plant material was weighed fresh and weighed again dry, while in Alcalde, fresh and dry weights were based on sampling. Samples of fresh material wereweighed, and then subsampleswereweighed fresh. The subsamples were dried in an oven for $48 \mathrm{~h}$ at $160^{\circ} \mathrm{F}\left(71^{\circ} \mathrm{C}\right)$ and reweighed. The dried to fresh weight was converted to a percentage, and used to estimate total dry weights of the sample, before being projected to a per-acre basis.

Although not part of the experiment, echinacea seed from both sites was harvested in the second year to sell. All of the valerian, yerba mansa and echinacea roots were sold. No attempt was made to sell the echinacea tops or aerial part of the plant even though an active market existsfor them. Although the flowers were harvested in the first summer in Las Cruces (but not sold), theflowering echinaceatopswere left in the field in the second summer so that entomologists could examine an invasion of sunflower moth ( $\mathrm{H}$ omoeosoma electellum ( $\mathrm{H}$ ulst)). Because of low market demand, the leaves of yerba mansa were not harvested for either yield information or sales even though traditional use of the plant includes preparation of teas with leaves. With the exception of minor quantities of fresh valerian and yerba mansa roots, all herb sales were of dried material.

At both sites, a randomized complete block design was used, with six treatments (two crops $\times$ three spacings) and four replicationsfor each plant spacing. Within-row spacings were 12,18 , and 24 inches $(30,45$, and $60 \mathrm{~cm})$. In L as $C$ ruces, each replication wasin abed $4 \mathrm{ft}$ wide by $30 \mathrm{ft}$ long $(1.2 \times 9.1 \mathrm{~m})$ and there were two rows of plants in each bed. At harvest time the border plantsat the end of each bed were ignored and the harvest area was $100 \mathrm{ft}^{2}\left(30.4 \mathrm{~m}^{2}\right)$ in the case of the 12 -inch spacing, and 90 and $80 \mathrm{ft}^{2}\left(27.4\right.$ and $\left.24.3 \mathrm{~m}^{2}\right)$ in the case of the 18- and 24-inch spacing. In Alcalde, the experiments were set up on rows typical for furrow irrigation in northern $\mathrm{N}$ ew $\mathrm{M}$ exico. Each plot consisted of two 36-inch $(91 \mathrm{~cm})$ rows on raised beds that were $30 \mathrm{ft}$ long $(9.12$ $\mathrm{m})$, or $180 \mathrm{ft}^{2}\left(54.7 \mathrm{~m}^{2}\right)$. The harvested area was $20 \mathrm{ft}$ long $\left(6.08 \mathrm{~m}^{2}\right)$, or $120 \mathrm{ft}^{2}$ $\left(36.5 \mathrm{~m}^{2}\right)$ per treatment plot. The yield data were analyzed using the general linear model procedure of SAS version 6.11 (SAS, 1990). An analysis of variancetest for randomized completeblock design was conducted. A more detailed presentation of theexperimentsisfound in Kleitz (1998).

Costs were classified as purchased inputs and transplant costs, preharvest, harvest, and postharvest operations. In addition to these categories of expenses, supervision and management and capital interest expense were estimated. Key cost assumptions are in Table 1. M ore detailed discussion of equipment and labor cost assumptionsarefound in $\mathrm{V}$ an Voorthuizen (1997).

T wo-year cost and return estimates were prepared for echinacea and valerian, because the root harvests took place after the second growing season. O ne-year costand return estimateswere prepared for yerba mansa as the root harvest took place after one growing season. Costs which required doubling for the 2-year estimates were water, weeding, and irrigation depreciation in L as Cruces. Input costs such as seeds, greenhouse supplies, Alaska fish fertilizer and manurewereincurred in year 1 . Although no additional fertilizer was applied in year 2 of the experiment, annual application of fertilizer may be necessary in perennial herb production.

$V$ al erian and echinaceaweregrown from transplantsstarted in agreenhouse, while yerba mansa was grown from crowns transplanted from the wild. H owever, the yerba mansa cost and return estimates include greenhouse costs for growing the crownsto a larger size, which may ensure greater survival rates. To the extent that crowns are taken directly from the wild (or another field) and transplanted immediately, greenhouse costs would be saved. The input costswere projected to 1 acre $(0.4$ ha), based on the amount used in the experiment, adjusted for the area of the plot.

Equipment usage costs were also estimated, although no field equipment was used in the experiments in Las $C$ ruces. Thetype of equipment assumed in the cost and return estimates were based on the equipment small farms tend to have available ( 50 horsepower tractor or less, transplanter, vegetable cultivator) or can be hired for custom work (disc, chisel, plow, bed shaper, 
Table 2. Cost assumptions for specialized postharvest equipment and facility, and purchased field equipment.

\begin{tabular}{|c|c|c|c|c|}
\hline Equipment & Purpose & $\begin{array}{l}\text { Purchase } \\
\text { cost }^{y}(\$)\end{array}$ & $\begin{array}{c}\text { Installation } \\
\text { cost (\$) }\end{array}$ & $\begin{array}{c}\text { U seful } \\
\text { life }\end{array}$ \\
\hline $\begin{array}{l}\text { N ursery lifter } \\
\text { Barn conversion }{ }^{w} \\
\text { Conveyor, } 0.75 \text { horsepower } \\
\text { Fan, } 15 \text { hp } \\
\text { Tractor, } 50 \text { horsepower } \\
\text { Vegetable cultivator } \\
\text { Roller bed shaper } \\
\text { Transplanter } \\
\text { Planter } \\
\text { Porterway harvester } \\
\text { Tool bar } \\
\text { H auling trailer } \\
\text { Combine } \\
\text { I rrigation system }\end{array}$ & $\begin{array}{l}\text { Root harvests } \\
\text { Batch dryer } \\
\text { T ake herbs to loft in barn } \\
\text { D ryer }\end{array}$ & $\begin{array}{c}500 \\
5,000 \\
500-2,000 \\
4,500 \\
14,500 \\
3,000 \\
800 \\
11,000 \\
2,500 \\
8,000 \\
1,250 \\
700 \\
3,500 \\
3,141 ; 7,829\end{array}$ & $\begin{array}{r}250 \\
2,250\end{array}$ & $\begin{array}{c}20 \\
15 \\
15 \\
15 \\
15 \\
15 \\
15 \\
16 \\
40 \\
25 ; 8\end{array}$ \\
\hline
\end{tabular}

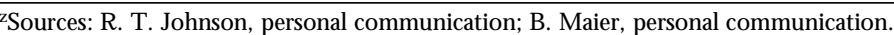

yWhere provided, ranges include used prices (low end) and new prices (high end).

${ }^{x}$ Assumed manufactured on farm.

wAssumes farm has existing barn with hay loft that is converted to a dryer.

vpolyvinyl chloride pipes, valves and flush ends; drip lines, injector pump and installation.

lister, rolling cultivator, swather). Equipment in the cost and return estimates also included equipment for washing, drying, and cutting the harvested crops (Table 2). The farm was assumed to be 10 acres (4 ha) for the purpose of selecting appropriate equipment.

To determinefield equipment fixed costs (depreciation plus taxes), accomplishment rateswereestimated (Sullivan et al., 1986) using the following equation: $\mathrm{AR}=1 /(\mathrm{ESP} \times \mathrm{W} \times 5280 \times(1 /$ 43560) $\times F E$ ) where $A R=$ accomplishment rate, $E S P=$ equipment speed in milesper hour, $\mathrm{W}=$ width in feet, 5280 $=\mathrm{ft}$ in 1 mile, $1 / 43560=$ acresper $1 \mathrm{ft}^{2}$, and $\mathrm{FE}=$ field efficiency rate.

An accomplishment rateistheproportion of total performancehourseach machine has for every pass across the field. Equipment speed and efficiency rates were obtained from Libbin and $\mathrm{H}$ awkes (1996). The accomplishment rateismultiplied by thesum of depreciation and taxes to determine the fixed costs of using the field equipment. Fuel and repair costs were also included in the equipment cost estimates.

Postharvest equipment costs(T able 2) were depreciated using straight line over a 7-year life with no salvage value. These costs were divided by 10 to get the per-acre estimates.

In the Las Cruces experiment, a surface drip system was used and weeding was done by hand. In Alcalde, furrow irrigation was used and both hand labor and a rolling tine cultivator were used for weed control. Since surface drip is not practical for farming opera-

Hor llechnology • O ctober-D ecember 1999 9(4) tions which cultivate with tractors, in the $L$ as Cruces cost and return estimates, the drip lines were assumed buried to allow mechanical cultivation for weed control. I n large scale commercial culinary and medicinal herb production near $L$ as $C$ ruces, significant weed problems have occurred. The irrigation system was depreciated in two parts; the drip lines and injector pump costing $\$ 7,829$ including installation were depreciated over 8 years, and the polyvinyl chloride (PVC) pipes, valves, and flush ends estimated to cost $\$ 3,141$ were assumed to havea25-year life(B. M aier, personal communication). Annual depreciation was divided by 10 to get the per-acre estimate (Table 2 ).

A sensitivity analysis for each cost and return estimate wasalso performed. Sensitivity analyses are important because often yields from experimental trials exceed those in commercial production because research teams usually can offer greater care to small plots to minimize any yield losses due to weeds, drought, postharvest handling, etc. The yield ranges were chosen to begin at approximatelythelowest level that would result in a negative return to land and risk with the price range selected, not to indicate how low yields could fall.

The prices in the cost and return estimates were those actually received in the project and are free on board (f.o.b.), or loaded at the packing house. Therange of sale prices of herbsused in the sensitivity analysiswere based on those published by Frontier H erbCooperativewholesaleprice catalog (Baker, 1997).
The products from these experiments were sold to buyers located using the H erbal Green Pages(Rogers, 1995) and the Natural Food Merchandiser (N ew H ope Communications, 1996). Small quantitieswere sold to local herbalists in Las Cruces, while larger quantitiesweresold to atincture manufacturer in northern $\mathrm{N}$ ew $\mathrm{M}$ exico and distributors in California and O regon. Of the herbs sold from the $\mathrm{N}$ ew $\mathrm{M}$ exico State U niversity (N M SU ) project (therewere 9 total), distributors in California and Oregon were particularly interested in echinacea and yerba mansa.

\section{Results and discussion}

Resultsof thisstudy suggest that in L as Cruces, 12 -inch (30-cm) spacing of echinacea and yerba mansa produces thegreatest yields(T able 3). In Alcalde, a statistically significant linear trend in yieldsdueto plant spacing wasfound for echinacea, but not for valerian (Table 4). At both sites, however, thetrend was increased mean yieldswith greater planting density. Return to land and risk for both crops at both sites were positive, using the 12-inch spacing and estimated market prices (T able 5). I n L as C ruces, the returns estimated are based on a planting density of 14,520 plants/ acre $(35,864$ plants/ ha) and in Alcalde, 13,068 plants/ acre( 32,278 plants/ ha).

In the case of echinacea and valerian roots, income in this analysis was considered available after two years. $\mathrm{H}$ owever, echinacea tops and seeds can be harvested during the first year of production. Echinaceahad good results 
T able 3. E chinacea (E chinacea purpurea) and yerba mansa (A nemopsis californica) yields in plant-spacing experiment, L as C ruces, N.M., 1996.

\begin{tabular}{lccc}
\hline $\begin{array}{l}\text { H erb } \\
\text { spacing }\end{array}$ & $\begin{array}{c}\text { Mean yield } \\
\text { dry wt } \\
\text { (Ib/acre) }\end{array}$ & SE & $\begin{array}{c}\text { L inear } \\
\text { effect }\end{array}$ \\
\hline Echinacea roots, 12-inch & 1,980 & 151.64 & $* * *$ \\
E chinacea roots, 18-inch & 1,560 & & \\
Echinacea roots, 24-inch & 914 & & $* * *$ \\
Yerba mansa roots, 12-inch & 3,890 & 133.80 & \\
Yerba mansa roots, 18-inch & 2,550 & & \\
Yerba mansa roots, 24-inch & 2,110 & &
\end{tabular}

zSource: Kleitz, 1998.

${ }^{\mathrm{y}} 1 \mathrm{lb} / \mathrm{acre}=1.12 \mathrm{~kg} \cdot \mathrm{ha}^{-1}$

${ }^{x} 1$ inch $=2.54 \mathrm{~cm}$.

${ }^{* * *}$ Linear effect significant at $p \leq 0.001$.

T able 4. E chinacea (E chinacea purpurea) and valerian (V aleriana officinalis) yields in plant-spacing experiment, Alcalde, N.M., 1996.

\begin{tabular}{lccc}
\hline $\begin{array}{l}\text { H erb } \\
\text { spacing }\end{array}$ & $\begin{array}{c}\text { Mean yield } \\
\text { dry wt } \\
\text { (Ib/acre) }\end{array}$ & SE & Linear \\
\hline Echinacea roots, 12-inchy & 1,860 & 143 & $*$ \\
Echinacea roots, 18-inch & 1,440 & & \\
E chinacea roots, 24-inch & 1,300 & 330 & NS \\
Valerian roots, 12-inch & 2,330 & & \\
Valerian roots, 18-inch & 1,870 & & \\
Valerian roots, 24-inch & 1,880 & & \\
\hline
\end{tabular}

${ }^{2} 1 \mathrm{lb} / \mathrm{acre}=1.12 \mathrm{~kg} \cdot \mathrm{ha}^{-1}$.

y1 inch $=2.54 \mathrm{~cm}$.

${ }^{*}$ Linear effect significant at $p \leq 0.05$.

at both sites even though income from tops and seeds was not included. Commercial growers of echinacea can sell topsfor between $\$ 1$ to $\$ 2 / \mathrm{lb}$ ( $\$ 2.21$ to $\$ 4.42 / \mathrm{kg}$ ) and seeds for $\$ 5 / \mathrm{lb}$
$(\$ 11.03 / \mathrm{kg})(\$ 15 / \mathrm{lb}$ or $\$ 33.08 / \mathrm{kg}$ for certified organic) (R. T. Johnson, personal communication). Echinacea tops can be harvested up to three times annually in Las C ruces. A seed or flow- ers-only harvest could substitute for a tops harvest. Commercial farms typically produce 2,000 to $8,000 \mathrm{lb} /$ acre $\left(2,240\right.$ to $\left.8,960 \mathrm{~kg} \cdot \mathrm{ha}^{-1}\right)$ of E. purpurea top material and $400 \mathrm{lb} /$ acre (448 $\mathrm{kg} \cdot \mathrm{ha}^{-1}$ ) of seed (R.T. Johnson, personal communication).

The sensitivity analysis performed for echinaceain $L$ as $C$ ruces showed that positive 2-year return to land and risk is obtained when root yieldsare $1,200 \mathrm{lb} /$ acre $\left(1,344 \mathrm{~kg} \cdot \mathrm{ha}^{-1}\right)$ and the price drops to $\$ 5 / \mathrm{lb}(\$ 11.03 / \mathrm{kg})$ (Table 6$)$. At $800 \mathrm{lb} /$ acre $\left(896 \mathrm{~kg} \cdot \mathrm{ha}^{-1}\right)$ yield, less than half of the average for 12 -inch spacing, and $\$ 5 / \mathrm{lb}(\$ 11.03 / \mathrm{kg})$, echinacea root returns fall just short of breaking even. Yerba mansa also had positive results. Yerbamansa sold for $\$ 4$ to $\$ 10 / \mathrm{lb}(\$ 8.82$ to $\$ 22.05 / \mathrm{kg})$ for dried root in 1996. Thesensitivity analysisfor thiscrop showed that a positive1year return to land and risk is made when yerba mansa is sold at $\$ 2 / \mathrm{lb}$ $(\$ 4.41 / \mathrm{kg})$ and when yieldsfall to 3,200 $\mathrm{lb} /$ acre $\left(3,584 \mathrm{~kg}^{\circ} \mathrm{ha}^{-1}\right)$ (Table 6).

In Alcalde, the sensitivity analysis showed at $\$ 10 / \mathrm{lb}(\$ 22.05 / \mathrm{kg})$ and $500 \mathrm{lb} /$ acre $\left(560 \mathrm{~kg} \cdot \mathrm{ha}^{-1}\right)$, echinacea still generatesa positive 2-year return to land and risk. At $\$ 4 / \mathrm{lb}(\$ 8.82 / \mathrm{kg})$, valerian yieldsneed to be $2,000 \mathrm{lb} /$ acre $\left(2,240 \mathrm{~kg} \cdot \mathrm{ha}^{-1}\right)$ in Alcalde to return $\$ 1,748$ over 2 years (Table 7).

Q uality affects the per-unit price that growersobtain for medicinal herbs. L ocal herbalistswill purchasefrom small

T able 5. E conomic results for echinacea (E chinacea purpurea), valerian (Valeriana officinalis), and yerba mansa (A nemopsis californica) in L as C ruces and Alcalde, N.M.,1996.

\section{Description}

Echinacea roots, 12-inch spacing ${ }^{z}$

Average yield (lb/ acrey $)$

Price $(\$ / \mathrm{lb})^{x}$

Gross income ( $\$ /$ acre $)^{w}$

Expenses (\$/ acre)

Return to land and risk after two seasons ( $\$$ / acre)

Yerba mansa roots, 12-inch spacing

Average yield (Ib/ acre)

Price $(\$ / \mathrm{lb})$

Gross income (\$/ acre)

Expenses ( $\$ /$ acre)

Return to land and risk from 1-year-old roots ( $\$$ / acre)

Valerian roots, 12 -inch spacing

Average yield (lb/ acre)

Price ( $\$ / \mathrm{lb})$

Gross income (\$/ acre)

Expenses ( $\$$ / acre)

Return to land and risk after two seasons ( $\$$ / acre)
L as C ruces

Alcalde

$\begin{array}{cc}1,978 & 1,857 \\ 12.00 & 12.00 \\ 23,736 & 22,284 \\ 7,643 & 7,672 \\ 16,093 & 14,612 \\ & \\ 3,885 & \mathrm{~N} / \mathrm{A} \\ 4.00 & \mathrm{~N} / \mathrm{A} \\ 15,540 & \mathrm{~N} / \mathrm{A} \\ 7,438 & \mathrm{~N} / \mathrm{A} \\ 8,102 & \mathrm{~N} / \mathrm{A} \\ & \\ \text { N / A } & 2,328 \\ \text { N / A } & 4.00 \\ \text { N / A } & 9,312 \\ \text { N / A } & 6,782 \\ \text { N / A } & 2,530\end{array}$

${ }^{2} 1$ inch $=2.54 \mathrm{~cm}$.

y1 lb/ acre $=1.12 \mathrm{~kg} \cdot \mathrm{ha}^{-1}$.

$\times \$ 1 / \mathrm{lb}=\$ 2.205 / \mathrm{kg}$.

$\mathrm{w} \$ 1 / \mathrm{acre}=\$ 2.47 / \mathrm{ha}$. 
Table 6. Estimated return to land and risk under varying price and yield combinations for echinacea ( $E$ chinacea purpurea) and yerba mansa (A nemopsis californica), Las Cruces, N.M.

\begin{tabular}{|c|c|c|c|c|}
\hline \multirow{2}{*}{$\begin{array}{l}\text { Yield } \\
\left.\text { (lb/acre }^{z}\right)\end{array}$} & \multicolumn{4}{|c|}{$\begin{array}{c}\text { Price } \\
\left(\$ / \mathbf{l b}^{y}\right)\end{array}$} \\
\hline & $\$ 5.00$ & $\$ 10.00$ & $\$ 12.00$ & $\$ 20.00$ \\
\hline $\begin{array}{l}800 \\
1,200 \\
1,400 \\
\text { Yerba mansa roots }\end{array}$ & $\begin{array}{l}(687)^{\mathrm{w}} \\
806 \\
1,546 \\
\mathbf{\$ 2 . 0 0} \\
\end{array}$ & $\begin{array}{c}\text { return t } \\
2,894 \\
6,177 \\
7,813 \\
\mathbf{\$ 4 . 0 0} \\
\end{array}$ & $\begin{array}{r}\text { d risk }(\$ / \\
4,327 \\
8,326 \\
10,319 \\
\mathbf{\$ 8 . 0 0} \\
\end{array}$ & $\begin{array}{l}10,056 \\
16,920 \\
20,345 \\
\mathbf{\$ 1 0 . 0 0} \\
\end{array}$ \\
\hline $\begin{array}{l}2,800 \\
3,200 \\
3,400\end{array}$ & $\begin{array}{l}(118) \\
344 \\
586\end{array}$ & $\begin{array}{c}\text { ar return } \\
4,896 \\
6,074 \\
6,674\end{array}$ & $\begin{array}{c}\text { id risk (\$) } \\
14,922 \\
17,538 \\
18,848\end{array}$ & $\begin{array}{l}19,935 \\
23,261 \\
24,936\end{array}$ \\
\hline
\end{tabular}

${ }_{1} 1 \mathrm{lb} /$ acre $=1.12 \mathrm{~kg} \cdot \mathrm{ha}^{-1}$.

$y \$ 1 / \mathrm{lb}=\$ 2.205 / \mathrm{kg}$.

$\times \$ 1 /$ acre $=\$ 2.47 /$ ha.

wN egative.

T able 7. Estimated return to land and risk under varying price and yield combinations for echinacea (E chinacea purpurea) and valerian (V aleriana officinalis), Alcalde, N.M.

\begin{tabular}{|c|c|c|c|c|}
\hline \multirow{2}{*}{$\begin{array}{l}\begin{array}{l}\text { Yield } \\
\text { (lb/acre })\end{array} \\
\text { Echinacea roots }\end{array}$} & \multicolumn{4}{|c|}{$\begin{array}{l}\text { Price } \\
\left(\$ / \mid b^{y}\right)\end{array}$} \\
\hline & $\$ 5.00$ & $\$ 10.00$ & $\$ 12.00$ & $\$ 20.00$ \\
\hline $\begin{array}{l}500 \\
1,400 \\
1,800\end{array}$ & $\begin{array}{l}(1,265)^{\mathrm{w}} \\
1,548 \\
2,798\end{array}$ & $\begin{array}{r}2 \text {-year return to } \\
973 \\
7,815 \\
10,855\end{array}$ & $\begin{array}{r}\text { d risk }(\$ / \\
1,869 \\
10,321 \\
14,078\end{array}$ & $\begin{array}{r}5,449 \\
20,347 \\
26,969\end{array}$ \\
\hline Valerian roots & $\$ 3.00$ & $\$ 4.00$ & $\$ 5.00$ & $\$ 6.00$ \\
\hline $\begin{array}{l}1,000 \\
2,000 \\
3,000\end{array}$ & $\begin{array}{c}(1,518) \\
(42) \\
1,433\end{array}$ & $\begin{array}{c}2 \text {-year return } t \\
(623) \\
1,748 \\
4,119\end{array}$ & $\begin{array}{r}\text { Id risk, \$/ } \\
272 \\
3,538 \\
6,804\end{array}$ & $\begin{array}{l}1,168 \\
5,329 \\
9,490\end{array}$ \\
\hline
\end{tabular}

${ }^{2} 1 \mathrm{lb} / \mathrm{acre}=1.12 \mathrm{~kg} \cdot \mathrm{ha}^{-1}$.

$y \$ 1 / \mathrm{lb}=\$ 2.205 / \mathrm{kg}$.

$\times \$ 1 /$ acre $=\$ 2.47 / \mathrm{ha}$.

wN egative.

local growers, and often pay a higher price per pound for small quantities of freshly harvested material, rather than buying from distant distributors whose product freshnessisless certain. Factors such as color, aroma, flavor, percentage extraneous matter, size, moisture content, presence of mold, and chemical analysis can affect price (Baker, 1997). The level of distribution channel-farm gate, first handler, wholesale distributor, processor-also affects prices.

Where in the marketing system a farmer can sell depends on farm size, and marketing functionsand processing operations performed. Value increases as additional processing is performed. In thebotanical medicinepyramid, fresh herb is at the base of the pyramid, followed by dried herb, tincture, extract, standardized extract, and phyto-

Horllechnology • O ctober-D ecember 1999 9(4) cals, I nc. can sell certified organ dried and cut root from the U.S. for
$\$ 12.70 / \mathrm{lb}(\$ 28 / \mathrm{kg})$ in 25-lb (11.35$\mathrm{kg})$ lots (Ernst, 1996). The N M SU research project received $\$ 8 / \mathrm{lb}$ $(\$ 17.64 / \mathrm{kg})$ for fresh, cleaned valerian root delivered within a few days of harvest to a tincture manufacturer in Santa Fe, N.M. Shipping fresh roots entails higher shipping charges than dried root to distant markets as some means (dried ice, ice packs) must be included to prevent mold. Whether prices are f.o.b. or cost, insurance and freight (c.i.f.) should be clarified. Prices for echinacea roots, tops, and seed also vary widely (Table 8 ).

O ften the per-unit price depends on whether a grower must move alarge quantity quickly to one or a few buyers versus whether a grower has the staff to pursue selling much smaller quantities to many different buyers. In addition, the services of an experienced herb broker can also help in obtaining the best possible price in the market. Experienced brokers will know most of the production regions and what acreage has been planted, whether unforeseen weather anomalies are expected to affect yields, import patterns, and the potential for bargaining for higher prices with manufacturers and other distributors. In this analysis, only a charge for management and supervision was included, although additional marketing costs may also be incurred if a broker is used or sales staff hired.

Theimportance of keeping tabson market prices and acreage expansion cannot be over emphasized. Compared to conventional field crops, medicinal herbs appear to be in the introductory phase of the product life cycle, with annually increasing demand. H owever, large medicinal herb acreage is in production around the globe, domestic and international conferences and trade shows draw thousands of participants and exhibitors, and market gluts can occur. For example, in Fall 1998 echinacea inventories increased to the point that pricesfor nonorganic echinacea fell below $\$ 12 / \mathrm{lb}(\$ 26.46 / \mathrm{kg})$ (R.T.Johnson, personal communication).

Although thisresearch analyzesthe potential financial outcomesof growing selected medicinal herbsin $N$ ew $M$ exico, more research is needed. Yield response to water and fertilizer applications is unknown. In addition, the effect on herb quality from irrigation, soil fertility, harvest timing, seed source, and plant age needs to be assessed. For example, application of high levels of 
T able 8. Selling prices of selected vendors of echinacea (E chinacea purpurea) and valerian (Valeriana officinalis) herbs and seeds, 1997.

\begin{tabular}{|c|c|c|c|c|}
\hline \multirow[b]{2}{*}{ Company } & \multicolumn{4}{|c|}{ Cost $\{\$ / l b[\text { lot size }(\mathrm{Ib})]\}^{\mathrm{v}}$} \\
\hline & Starwest $^{2}$ & Good H ope' & Richters $^{x}$ & Johnny's ${ }^{w}$ \\
\hline \multicolumn{5}{|l|}{ Echinacea } \\
\hline Certified organic seeds & & & & 115 \\
\hline Certified organic cut/ dried tops & $11.05[25]$ & & & \\
\hline Certified organic cut/ dried roots & $34.00[25]$ & & & \\
\hline N oncertified organic seeds & & & 68.55 & 35 \\
\hline N oncertified organic cut/ dried tops & $8.50[25]$ & 24.97 & & \\
\hline N oncertified organic cut/ dried roots & $22.35[25]$ & $32.00[25]$ & 96.70 & \\
\hline \multicolumn{5}{|l|}{ Valerian } \\
\hline Certified organic cut/ dried roots & $12.70[25]$ & & & \\
\hline N oncertified organic seeds & & & 680.27 & 182 \\
\hline N oncertified organic cut/ dried roots & $3.20[25]$ & $3.02[25]$ & 34.47 & \\
\hline
\end{tabular}

zErnst, 1996.

yGood H ope Botanicals, 1997.

xRichters, 1997.

wJ ohnny's Selected Seeds, 1997

$\mathrm{v} \$ 1 / \mathrm{lb}=\$ 2.205 / \mathrm{kg} .1 \mathrm{lb}=0.454 \mathrm{~kg}$

nitrogen and medium levels of potassium has been linked to higher levels of alkylamidesin E. purpurea (EI-Gengaihi, et al., 1998). Alkylamides are responsible for the numbing and tingling sensations produced by echinacea and are desired compounds(Foster, 1999). The medicinal herb market is moving toward payments of bonuses to growers who can increase the content of marker compounds in selected herbs, such as echinacea, where standardization of herbal preparationsiscommon. In such cases, growers are being asked to providelaboratoryanalysesalong with product samples, and such tests can cost $\$ 200$ to $\$ 500$ depending on the number of tests run.

An additional caveat is in order. Thisstudy projected the financial return to a small-scale operation in which minor investments in a converted barn batch drying facility areassumed. L arger scalefarming will requiremedicinal herb growers to either lease or build facilities capable of handling the washing, chopping, drying, and cleaning requirements for larger quantities of root, top, and seed material. In a region such as northern $\mathrm{N}$ ew $\mathrm{M}$ exico, such facilities cooperatively managed might be an appropriatestrategy for arelatively small farm producing medicinal herbs.

\section{Literature cited}

Baker, G. 1997. Frontier Cooperative $\mathrm{H}$ erbs grower information. Frontier $\mathrm{Co}$ operative $\mathrm{H}$ erbs, N orway, I owa.

Brevoort, P. 1998. The booming U.S. botanical market: A new overview. H erbalG ram. 44:33-48.
El-Gengaihi, S.E., A.S. Shalaby, E.A. Agina, and S.F. H endawy. 1998. Alkylamides of Echinacea purpurea $L$. as influenced by plant ontogeny and fertilization. J. H erbs, Spices, M edicinal Plants. 4:35-41.

Ernst, D.E. (ed.). 1996. Starwest Botanicals, Inc. wholesale catalog, fall/ winter 1996-97. Startwest Botanicals, Inc. R ancho Cordova, Calif.

Foster, S. 1991. Echinacea, nature's immune enhancer. $\mathrm{H}$ ealing Art Press, Rochester, Calif.

Foster, S. 1999. Fertilizer may affect echinaceapotency. $\mathrm{H}$ erbsfor H ealth (J an./ Feb.):81.

Good H ope Botanicals. 1997. Wholesale catalog 1997. Good Hope Botanicals, N ovato, Calif.

H errera, E. 1989. Average freeze-free periods by weather stations during 1982 1987 seasons, N.M. State U niv. Coop. Ext. Guide $\mathrm{H}-111$.

Hobbs, C. 1993. Valerian, the relaxing and sleep herb. Botanica Press, Capitola, Calif.

J ohnny's Selected Seeds. 1997. 1997 commercial catalog. Johnny's Selected Seeds, Albion, $M$ aine.

Kleitz, K.M. 1998. Medicinal herb production in $\mathrm{N}$ ew M exico. M S thesis. N .M . State U niv., Las Cruces.

Knight, J. 1999. Plants at risk. H erbs for H ealth. ( $M$ ay/ June):49.

Libbin, J. and J. H awkes. 1996. Estimated prices, yields and selected production parameters used in budgeting cost and returns for 1996. N ew M exico State U niv. Coop. Ext., Las Cruces.

Libbin, J. and J. H awkes. 1997. Estimated prices, yields and selected production parameters used in budgeting cost and returns for 1997. N ew M exico State U niv. Coop. Ext., Las Cruces.
M oore, M . 1989. M edicinal plants of the desert and canyon west. M useum of N .M. Press, Santa Fe.

Moore, M. 1990. Los Remedios, traditional herbal remedies of the Southwest. Red Crane Books, Santa Fe, N .M .

$\mathrm{N}$ ew H ope Communications, Inc. 1996. $\mathrm{N}$ atural food merchandiser 1997 retailer purchasing guide. $\mathrm{N}$ ew H ope Commun., Inc., Boulder, Colo.

N ew M exico State U niversity. 1998. N ew $M$ exico Climate $C$ enter, climate data conversion and data retrieval. $\mathrm{N}$ ew M exico C limate Center, Dept. of Agronomy and $\mathrm{H}$ orticulture. N.M. State U niv. $5 \mathrm{~N}$ ov. 1998 <http:/ / weather.nmsu.edu/ convert.html>.

Richters. 1997. H erb catalogue1997. O tto Richter and Sons Ltd., Goodwood, O nt., C anada.

Rogers, M . (ed.). 1995. H erbal green pages: An herbal resource guide. $\mathrm{H}$ erb Growing and $\mathrm{M}$ arketing $\mathrm{N}$ etwork, Silver Spring, $\mathrm{Pa}$.

SAS I nstitute. 1990. SAS language: reference version 6. 1st ed. SAS Inst., Cary, N.C.

Starman, T.W., T.A. Cerny, and A.J. $M$ ack enzie. 1995. Productivity and profitability of some field-grown specialty cut flowers. H ortScience 30(6):1217-1220.

Sullivan, R.P., M .J. Schaber, J.D. Libbin, and B.E. M ayberry. 1986. M icrocomputer crop cost and return generator technical documentation. N.M. Agr. Expt. Sta. Bul. 726.

Van Voorthuizen, H . 1997. The economics of growing medicinal herbs in $\mathrm{New}$ M exico. M S thesis. N .M . State U niv., L as Cruces. 